\title{
Synthesis of $\mathrm{K}_{2}$ Se solar cell dopant in liquid $\mathrm{NH}_{3}$ by solvated electron transfer to elemental selenium
}

\author{
D. Colombara ${ }^{\mathrm{a}, \mathrm{b}, *}$, A.-M. Gonçalves ${ }^{\mathrm{b}}$, A. Etcheberry ${ }^{\mathrm{b}}$ \\ ${ }^{a}$ Université du Luxembourg, Physics and Materials Science Research Unit - 41, Rue du Brill, L-4422 Belvaux, Luxembourg \\ ${ }^{\mathrm{b}}$ Université de Versailles, Institut Lavoisier de Versailles - 45, Avenue des États Unis, 78000 Versailles, France
}

\section{A R T I C L E I N F O}

\section{Keywords:}

Solvated electron

Liquid ammonia

Microelectrode

Alkali metal selenide extrinsic doping

Chalcopyrite

Copper indium gallium diselenide

\begin{abstract}
A B S T R A C T
This study explores the rich chemistry of elemental selenium reduction to monoselenide anions. The simplest possible homogeneous electron transfer occurs with free electrons, which is only possible in plasmas; however, alkali metals in liquid ammonia can supply unbound electrons at much lower temperatures, allowing in situ analysis. Here, solvated electrons reduce elemental selenium to $\mathrm{K}_{2} \mathrm{Se}$, a compound relevant for alkali metal doping of $\mathrm{Cu}(\mathrm{In}, \mathrm{Ga}) \mathrm{Se}_{2}$ solar cell material. It is proposed that the reaction follows pseudo first-order kinetics with an inner-sphere or outer-sphere oxidation semi reaction mechanism depending on the concentration of solvated electrons.
\end{abstract}

\section{Introduction}

Alkali metals play a crucial role in the world's most efficient solar cell devices based on the chalcopyrite $\mathrm{Cu}(\mathrm{In}, \mathrm{Ga}) \mathrm{Se}_{2}$ (CIGS) semiconductor, where they act as extrinsic dopants [1-3]. This has been known since the 1990s, when sodium was shown to dramatically improve the solar cell's open circuit voltage. The mechanisms by which sodium affects the composition $[4,5]$, structure [6, 7], and optoelectronic properties [8, 9] of CIGS are still under debate. Recently, potassium [10, 11] and the heavier alkali metals [12] have increased performance up to the staggering $22.9 \%$ record value established by Solar Frontier [13].

It was originally suggested by Braunger et al. that sodium segregates as selenides at CIGS grain boundaries [14], and this was then confirmed by atom probe tomography [15]. Importantly, alkali metals are thought to catalyse the oxygenation of CIGS grain boundaries, passivating structural defects normally present at such interfaces [16]. However, it is not known if this beneficial effect is due to the alkali metal cations, the (poly)selenide anions or both. Knowledge of these compounds beyond computational studies [17] is simply insufficient to draw conclusions in this regard. Therefore, the synthesis of alkali metal selenide compounds and the study of their redox chemistry are necessary preconditions for fundamental developments in the field, also in view of the as-yet surprising phenomenon of gas-phase alkali metal doping [18].

Solutions of alkali metals and ammonia have been known since the pioneering work of Sir Humphry Davy [19] and have been used since the 1930s as powerful reducing agents in both organic and inorganic synthesis [20-23]. It was first proposed by Kraus [24, 25] and has subsequently been accepted that alkali metals dissociate at least partially into alkali cations and solvated electrons under the action of liquid ammonia (reaction 1 ), where $\mathrm{Ak}$ is a generic alkali element:

$\mathrm{Ak}_{(\mathrm{s})} \stackrel{\mathrm{NH}_{3}}{\longrightarrow} \mathrm{Ak}_{\left(\mathrm{NH}_{3}\right)} \rightleftharpoons\left\{\mathrm{Ak}^{+} \mathrm{e}^{-}\right\}_{\left(\mathrm{NH}_{3}\right)} \rightleftharpoons \mathrm{Ak}_{\left(\mathrm{NH}_{3}\right)}^{+}+\mathrm{e}_{\left(\mathrm{NH}_{3}\right)}^{-}$

Computational work by Chandra and Marx [26] and Hoffmann et al. [19] confirms that sufficiently diluted solutions contain unbound electron species near empty cavities of the solvent. Therefore, such systems contain the smallest possible anion [27] and constitute the ultimate environment for electron transfer processes in homogeneous media. These are in contrast to electron transfers to or from the surface of electrodes immersed in solution, which form a heterogeneous interface [28, 29].

According to Henry Taube's theory, the limiting pathway for electron transfer may involve the formation or cleavage of chemical bonds. If bonds are formed or broken, the process is called inner-sphere electron transfer. Conversely, during outer-sphere transfer, electrons tunnel through space upon contact with the redox-active species via diffusion or supramolecular interaction [30].

Synthetic research on liquid ammonia is vast, but is mostly devoted to organic synthesis [31, 32]. Inorganic systems have received less attention, with the focus more on applications than the fundamentals of chemical kinetics [33, 34].

The present study investigates the reduction of elemental selenium

\footnotetext{
* Corresponding author at: Université du Luxembourg, Physics and Materials Science Research Unit - 41, Rue du Brill, L-4422 Belvaux, Luxembourg.

E-mail address: diego.colombara@bath.edu (D. Colombara).
} 


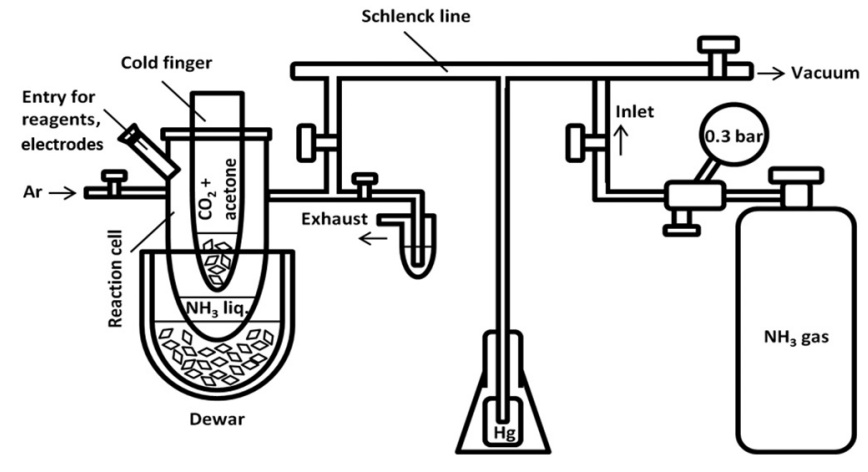

Fig. 1. Schematic diagram of the rig employed for the synthesis and electrochemical kinetic study of the reaction between elemental potassium and selenium in liquid ammonia.

to selenide in liquid ammonia by the action of dissolved elemental potassium. This is a special case of electron transfer in which the oxidizer undertakes bond cleavage, while the reductant is the solvated electron itself. Here, the decrease in solvated electron concentration during the course of the reaction is monitored by direct measurements: fully reversible solvated electron oxidation via cyclic voltammetry (CV) at the surface of a microelectrode.

\section{Materials and methods}

The study is carried out in pure liquid ammonia at $-50{ }^{\circ} \mathrm{C}$, following a route modified from Sharp and Koehler's approach [35]. A standard Schlenck line is connected to a bottle reservoir of ammonia for condensation [36] (Fig. 1). The reaction vessel was especially designed and custom-made for this experiment. It is composed of a $50 \mathrm{ml}$ threeentry cell with a central bore. The entries are for Ar gas purge, insertion of reagents/electrodes and a security exhaust. A cold finger is placed to rest on the central bore of the cell and a dry ice/acetone mixture is put inside. The whole cell is also partially submerged in a double-walled glass Dewar containing the same cooling mixture. The condensation of ammonia proceeds at a rate of ca. $1 \mathrm{ml} \cdot \mathrm{min}^{-1}$ at a safe pressure of less than half a bar. A Pt microelectrode $(20 \mu \mathrm{m}$ diameter $)$ is used as the working electrode; in order to ensure an unchanged surface area, the electrode was calibrated with a ferrocene solution before and after the experiments. The reference electrode is a silver wire held in protective tubing with a bottom frit, to avoid any potential drift due to solvated electron attack [37]. Stoichiometric amounts of Se shot (2 mm diameter) or powder (99.999\%, Alfa Aesar) and potassium (99.95\%, Alfa Aesar) were weighed inside a nitrogen-filled glovebox and placed in sealable glass transportation vials. The potassium was sandwiched between two quartz platelets and immersed in n-hexane, in order to ease transfer into the reaction vessel while minimizing oxidation and adhesion of potassium to the walls of the transportation vials. The initial potassium concentration for the kinetic study is kept low at ca. $0.01 \mathrm{M}$ to limit the presence of ion-paired species [38]. Larger quantities of $\mathrm{K}$ and Se are used for a parallel synthetic run performed for identification of the product.

\section{Results and discussion}

The CVs of solvated electron oxidation reveal a very good overlap between forward and reverse scans, showing no hysteresis resulting from overpotential at the Pt microelectrode, and an open circuit potential of $-2.42 \mathrm{~V}$ vs Ag, consistent with previous studies [39]. Furthermore, the neat stationary current plateau demonstrates that the measurement of anodic current is ideal for accurate detection of solvated electron concentration (Fig. 2a). Microdisc electrodes are not uniformly accessible by the electrolyte [40], but the stationary current density $j_{l}$ averaged over the microelectrode surface depends only on the bulk solvated electron concentration $\left[\mathrm{e}_{\text {bulk }}{ }^{-}\right]$and on its diffusion coefficient $D$, as shown in Eq. (2) [41].

$j_{l}=\frac{4 n \mathrm{~F} D\left[\mathrm{e}_{\text {bulk }}^{-}\right]}{\pi r}$

Taking into account the value of $\left[\mathrm{e}_{\mathrm{bulk}}{ }^{-}\right.$] determined from the mass of $\mathrm{K}$, the volume of condensed $\mathrm{NH}_{3}$ and the microelectrode radius $r, D$ is determined to be $9.4 \cdot 10^{-5} \mathrm{~cm}^{2} \mathrm{~s}^{-1}$ for the solvated electron at $-50^{\circ} \mathrm{C}$; a value consistent with previous accounts [42, 43].

Upon addition of selenium, $\left[\mathrm{e}_{\text {bulk }}{ }^{-}\right.$] decreases as shown by the drop in the current plateau (dotted CV, Fig. 2a). Thus, the kinetics of selenium reduction can be monitored electrochemically by repeatedly probing the decrease in the stationary current and translating it into [e $\mathrm{e}_{\text {bulk }}{ }^{-}$].

The kinetic data is converted into first- and second-order integrated rate formats in Fig. 2b. It appears that the reduction of elemental selenium to $\mathrm{Se}^{2-}$ by the action of solvated electrons in liquid ammonia proceeds for most of the time with pseudo first-order kinetics with respect to the solvated electron.

Thanks to the bright distinctive colors of the polyselenide anions [35, 44-47], inspection of the synthesis run provides a rich wealth of visual information that simplifies the interpretation of the results (Fig. 2c). A heterogeneous reaction starts at the surface of the Se pellets (reaction (3)):

$\mathrm{Se}_{z(\mathrm{~s})}+2 \mathrm{~K}_{\left(\mathrm{NH}_{3}\right)}^{+}+2 \mathrm{e}_{\left(\mathrm{NH}_{3}\right)}^{-} \rightleftharpoons 2 \mathrm{~K}_{\left(\mathrm{NH}_{3}\right)}^{+}+\mathrm{Se}_{z\left(\mathrm{NH}_{3}\right)}^{2-}$

The elemental selenium employed here is the commercial-grade black vitreous form. This is mainly composed of $\mathrm{Se}_{8}$ rings, along with some distorted chains or opened rings [48], though polymeric rings with up to 1000 atoms have been reported [49]. It is likely that polyselenide ions $\left.\mathrm{Se}_{z\left(\mathrm{NH}_{3}\right.}\right)^{2-}$ with a range of $z$ ( $z$ being the original number of Se atoms in the ring) would form through reaction (3). Although

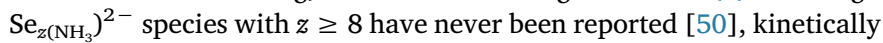
speaking, they are the most obvious adduct of $\mathrm{Se}_{z}$ rings and two solvated electrons, requiring the cleavage of just one bond.

Radical $\mathrm{Se}_{z\left(\mathrm{NH}_{3}\right)^{-}}$may form by the action of one solvated electron on $\mathrm{Se}_{z}$, followed by capture of a second solvated electron to give

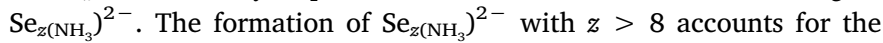
blackish coloration near the surface of the Se pellets, as observed in Fig. $2 \mathrm{c}$ at $1 \mathrm{~h} 40 \mathrm{~min}$ ( $\mathrm{Se}_{8}$ is red). The lifetime of such a species is short under the strongly reducing environment ensured by the large supply of solvated electrons. Therefore, reaction (3) is followed by further reductions in the homogeneous phase (reaction (4)), as shown by the color gradient stemming from the Se pellets: black $\rightarrow$ dark red $\rightarrow$ light brown $\rightarrow$ white (magnified area in Fig. 2c), which is consistent with the hypsochromic shift associated with a shortening of the polyselenide chains to $\mathrm{Se}^{3-}$ [51, 52]. The light brown coloration formed near the white $\mathrm{K}_{2} \mathrm{Se}$ is consistent with a mixture of $\mathrm{Se}^{3-}$ (bright green) and $\mathrm{Se}^{2-}$ (bright red).

$\mathrm{Se}_{z\left(\mathrm{NH}_{3}\right)}^{2-}+2 n \mathrm{e}_{\left(\mathrm{NH}_{3}\right)}^{-} \rightleftharpoons \mathrm{Se}_{z-n\left(\mathrm{NH}_{3}\right)}^{2-}+n \mathrm{Se}_{\left(\mathrm{NH}_{3}\right)}^{2-}$

Reaction (4) occurs in the homogeneous phase and proceeds in steps (not necessarily sequential, given that $\mathrm{Se}^{3-}$ and $\mathrm{Se}^{2-}$ appear to coexist), forming polyselenides with $n$ ranging from 1 to $z$ - 1 until all the solvated electrons are consumed, ultimately leading to $\mathrm{K}_{2} \mathrm{Se}$, as confirmed by the X-ray diffractogram (XRD) shown in Fig. 2d.

The kinetic rate of reaction (4) can be expressed in terms of the consumption of solvated electron and the formation of (poly)selenide anions with time, as follows (Eq. (5)):

$v=-\frac{\partial\left[\mathrm{e}_{\left(\mathrm{NH}_{3}\right)}^{-}\right]}{2 \partial t}=\sum_{n=1}^{z} \frac{\partial\left[\mathrm{Se}_{n\left(\mathrm{NH}_{3}\right)}^{2-}\right]}{\partial t}=k \cdot\left[\mathrm{e}_{\left(\mathrm{NH}_{3}\right)}^{-}\right]^{\alpha} \cdot \prod_{n=1}^{z}\left[\mathrm{Se}_{n\left(\mathrm{NH}_{3}\right)}^{2-}\right]^{\beta_{n}}$

In the timeframe corresponding to the linear region of Fig. $2 \mathrm{~b}$, the kinetic parameters are as follows: $\alpha=1$ and $k=1.6 \cdot 10^{-4} \mathrm{~s}^{-1}$ at 

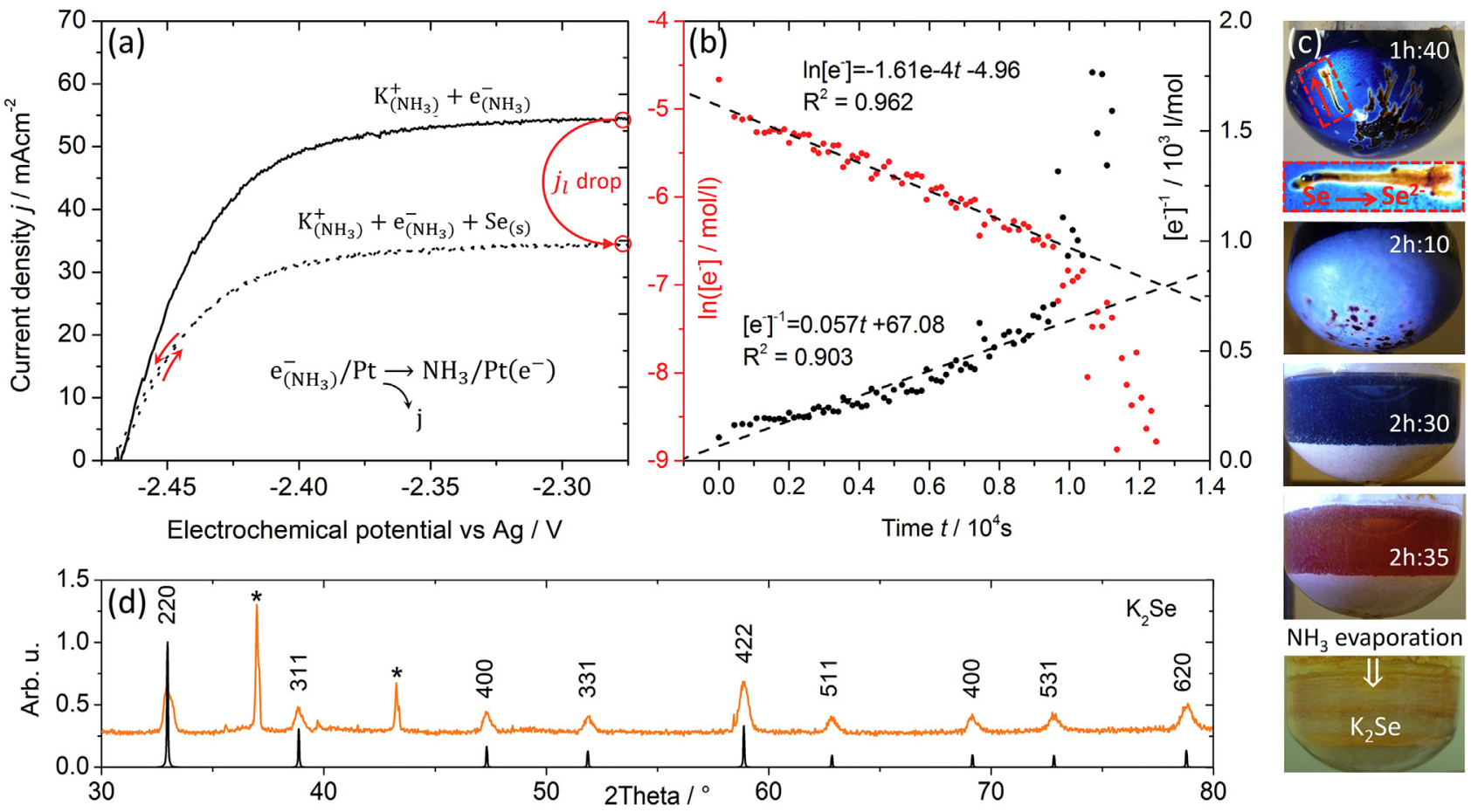
80

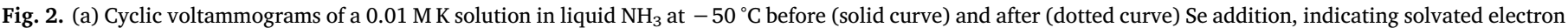

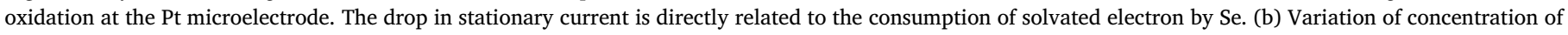

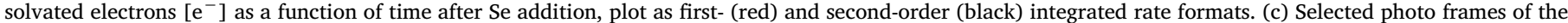

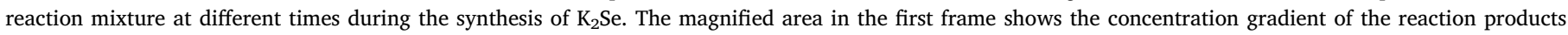

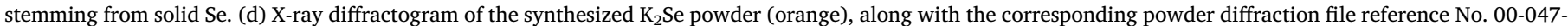

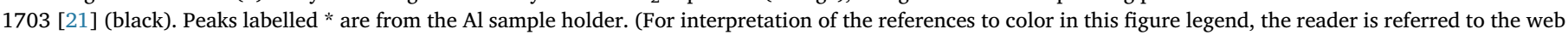
version of this article.)

$-50{ }^{\circ} \mathrm{C}$, while $\beta_{n}$ remains inaccessible. The time independence of the electron transfer rate is attributed to a similar electron transfer rate for the various $\mathrm{Se}_{n\left(\mathrm{NH}_{3}\right)^{2-}}$ species formed during the reaction, in which case the measured rate corresponds to the average electron transfer rate to the distribution of $\mathrm{Se}_{n\left(\mathrm{NH}_{3}\right)^{2-}}$ species. Two additional kinetic regimes are identified during the reaction. One at the very beginning, when Se has just been added to the electron ammonia solution, and one when the concentration of solvated electrons drops to approximately $10 \%$ of the initial concentration (beyond the second last photo frame of Fig. 2c). In both cases a higher reaction rate is observed. The initial and final rates correspond to electron transfer respectively to the pristine

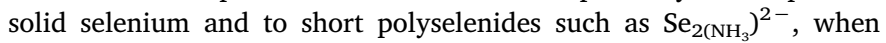
longer chains have been consumed.

Analysis of the electrochemical transients upon selenium insertion provides additional insights into the elusive chemistry of solvated electrons in this system. The potential dependence of the current density $j$ is described by the Tafel relation (Eq. (6)) as follows [41]:

$\ln (j)=\ln \left(j_{0}\right)+\frac{\alpha_{\mathrm{a}} \mathrm{F}}{\mathrm{R} T} \cdot \eta$

where $j_{0}$ is the exchange current density, $\alpha_{\mathrm{a}}=\mathrm{RT} / \mathrm{F}(\mathrm{d} \ln (j) / \mathrm{d} \eta)$ is the anodic charge transfer coefficient (i.e. independent of $n$ ) [53], $\mathrm{R}$ is the universal gas constant, $T$ the absolute temperature and $\eta$ the electrochemical overpotential.

Fig. 3a shows an exemplary Tafel analysis. The slope of the linear fit to the curves well below $20 \%$ of the limiting current (i.e. in the electrochemical kinetic limitation regime) provides an estimate of $\alpha_{\mathrm{a}}$. The inset in Fig. 3a shows the simultaneous variation of $\alpha_{\mathrm{a}}$ and $\left[\mathrm{e}_{\mathrm{bulk}}{ }^{-}\right]$ with time before and after addition of solid Se to the potassiu$\mathrm{m}$-ammonia solution. Clearly, the decrease in $\left[\mathrm{e}_{\text {bulk }}{ }^{-}\right.$] is accompanied by an increase in $\alpha_{\mathrm{a}}$.

The interdependence between $\alpha_{\mathrm{a}}$ and [ $\mathrm{e}_{\mathrm{bulk}}{ }^{-}$] is evaluated in Fig. 3b throughout the entire kinetic dataset. The large spread of $\alpha_{a}$ at low $\left[\mathrm{e}_{\text {bulk }}{ }^{-}\right.$] is simply the result of diffusion limitation affecting the shape of the current transients. However, $\alpha_{\mathrm{a}}$ increases on average from high to medium solvated electron concentration $\left(10 \mathrm{mmol} / 1>\left[\mathrm{e}_{\text {bulk }}{ }^{-}\right]>5\right.$ $\mathrm{mmol} / \mathrm{l}$ ) (red arrow). This increase may be attributed to a decrease in the concentration of $\left.\left\{\mathrm{K}^{+} \mathrm{e}^{-}\right\}_{\left(\mathrm{NH}_{3}\right.}\right)$ ion-paired species.

Both the consumption of $\mathrm{e}_{\left(\mathrm{NH}_{3}\right)^{-}}$and the sequestration of $\mathrm{K}_{\left(\mathrm{NH}_{3}\right)^{+}}$ due to the formation of (poly)selenide anions are likely to induce a rightward shift of equilibrium (reaction (7)), according to Le Chatelier's principle.

$\left\{\mathrm{K}^{+} \mathrm{e}^{-}\right\}_{\left(\mathrm{NH}_{3}\right)} \rightleftharpoons \mathrm{K}_{\left(\mathrm{NH}_{3}\right)}^{+}+\mathrm{e}_{\left(\mathrm{NH}_{3}\right)}^{-}$

This scenario is consistent with a transition from dilute to very dilute solvated electron solutions, as proposed by Hoffmann et al. for the analogous $\mathrm{Li}-\mathrm{NH}_{3}$ system [19]. At sufficiently low alkali metal concentrations, reaction (7) leans towards the right-hand side, where solvated electrons are unbound, while at higher concentrations ion pairing with the alkali cation prevails.

The oxidation of non-paired solvated electrons is thermodynamically more facile compared to the case where electrons and potassium cations are paired, due to the pairing stabilization energy (see schematics in Fig. 3b). Upon Se addition, the concentration of ionpaired species would decrease according to (reaction (7)) and this coincides with the observed increase in the charge transfer coefficient. Given that the pairing bond energy is expected to be non-negligible [54] ( $>0.8 \mathrm{~kJ} / \mathrm{mol}$ for $\mathrm{Li}-\mathrm{NH}_{3}$ [19]), the increase in $\alpha_{\mathrm{a}}$ could be consistent with a transition from an inner- to an outer-sphere mechanism of electron oxidation at the Pt microelectrode, explained on the basis of an increased proportion of unbound solvated electrons in solution. If this could be confirmed, the kinetics of selenium reduction would appear to be roughly insensitive to the paired or unpaired nature of the solvated electron species. 

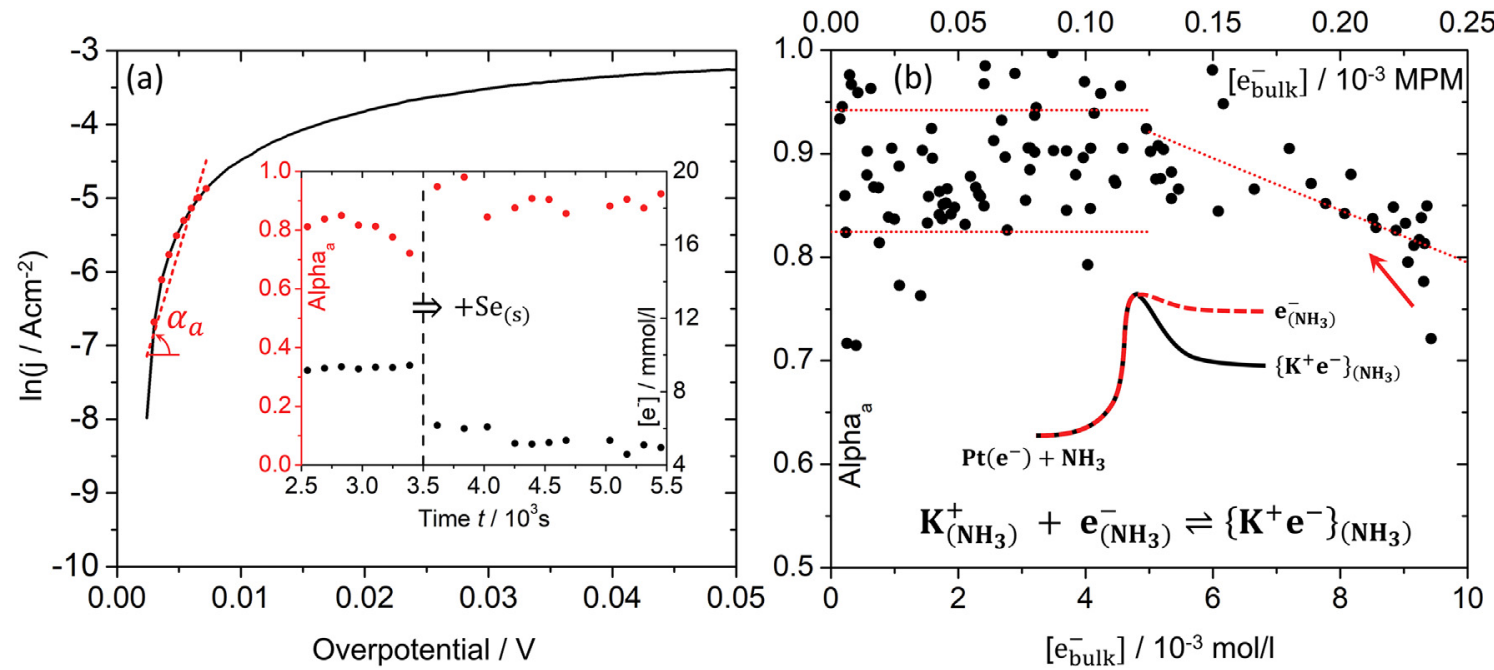

Fig. 3. (a) Tafel analysis aimed at extracting the anodic charge transfer coefficient $\alpha_{a}$ from the slope of the linear fit in the kinetic limited region. Inset: variation of $\alpha_{a}$ (red) and $\left[\mathrm{e}_{\mathrm{bulk}}{ }^{-}\right.$] (black dots) before and after addition of Se to the $\mathrm{K}^{-\mathrm{NH}_{3}}$ solution. (b) Dependence of $\alpha_{\mathrm{a}}$ upon [e $\mathrm{e}_{\text {bulk }}{ }^{-}$] during the entire kinetic study, the dotted lines are the $\pm 1 \sigma$ confidence values (left) and the least squares fitting (right) of the data distribution, the red arrow is for discussion purposes. Schematics: illustrative

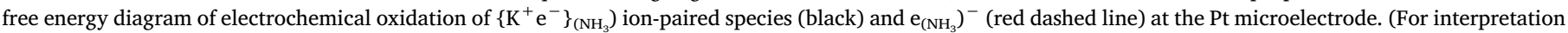
of the references to color in this figure legend, the reader is referred to the web version of this article.)

\section{Conclusions}

This study reveals that the reduction of elemental selenium to monoselenide occurs via a pseudo first-order reaction with respect to solvated electrons in liquid ammonia. The kinetics are determined by direct electrochemical detection of the solvated electron concentration via reversible oxidation at the surface of a microelectrode. Upon addition of selenium, the anodic charge transfer coefficient increases. This suggests a faster solvated electron oxidation semi reaction, which may relate to a shift from an outer-sphere to an inner-sphere mechanism, caused by the shift of the electron pairing equilibrium with potassium cations. If confirmed, this shift does not appear to alter the rate order of the selenium reduction. The results provide basic insights into the redox chemistry of selenide anions and will serve as a platform for in-situ investigation of alkali metal selenides as catalysts for the oxygenation of CIGS surfaces and grain boundaries, which is one possible reason for the observed solar cell performance enhancement upon alkali metal doping.

\section{Acknowledgements}

DC wishes to thank the Luxembourg National Research Fund (FNR) for funding this research study under the GALDOCHS (Gas-phase alkali doping of chalcogenide semiconductors) project C14/MS/8302176 and for his Core Junior Fellowship. The group at ILV is acknowledged for hospitality during this collaborative research in Versailles. Special thanks go to Fabrice Zuccarelli, (Université de Versailles) for the swift and impeccable fabrication of the custom-made glassware. We thank Prof. Phillip Dale (University of Luxembourg) for feedback and Prof. Colm O'Dwyer (University College Cork) for his invitation to the 231st Electrochemical Society meeting in New Orleans, where part of this study was presented.

\section{Conflicts of interest}

The authors declare no competing interests.

\section{References}

[1] I. Repins, M.A. Contreras, B. Egaas, C. DeHart, J. Scharf, C.L. Perkins, B. To, R. Noufi, $19 \cdot 9 \%$-efficient $\mathrm{ZnO} / \mathrm{CdS} / \mathrm{CuInGaSe}^{2}$ solar cell with $81 \cdot 2 \%$ fill factor,
Prog. Photovolt. Res. Appl. 16 (2008) 235-239, http://dx.doi.org/10.1002/pip. 822 .

[2] A. Chirilă, S. Buecheler, F. Pianezzi, P. Bloesch, C. Gretener, A.R. Uhl, C. Fella, L. Kranz, J. Perrenoud, S. Seyrling, R. Verma, S. Nishiwaki, Y.E. Romanyuk, G. Bilger, A.N. Tiwari, Highly efficient $\mathrm{Cu}(\mathrm{In}, \mathrm{Ga}) \mathrm{Se}_{2}$ solar cells grown on flexible polymer films, Nat. Mater. 10 (2011) 857-861, http://dx.doi.org/10.1038/ nmat3122.

[3] P. Jackson, D. Hariskos, E. Lotter, S. Paetel, R. Wuerz, R. Menner, W. Wischmann, M. Powalla, New world record efficiency for $\mathrm{Cu}(\mathrm{In}, \mathrm{Ga}) \mathrm{Se}_{2}$ thin-film solar cells beyond 20\%, Prog. Photovolt. Res. Appl. 19 (2011) 894-897, http://dx.doi.org/10. 1002/pip.1078.

[4] D. Colombara, F. Werner, T. Schwarz, I.C. Infante, Y. Fleming, N. Valle, C. Spindler, E. Vacchieri, G. Rey, M. Guennou, M. Bouttemy, A. Garzón Manjón, I. Peral Alonso, M. Melchiorre, B. El Adib, B. Gault, D. Raabe, P.J. Dale, S. Siebentritt, Sodium enhances indium-gallium interdiffusion in copper indium gallium diselenide, Nat. Commun. 9 (2018) 826.

[5] H. Rodriguez-Alvarez, R. Mainz, R. Caballero, D. Abou-Ras, M. Klaus, S. Gledhill, A. Weber, C.A. Kaufmann, H.-W. Schock, Real-time study of Ga diffusion processes during the formation of $\mathrm{Cu}(\mathrm{In}, \mathrm{Ga}) \mathrm{Se}_{2}$ : The role of $\mathrm{Cu}$ and Na content, Sol. Energy Mater. Sol. Cells 116 (2013) 102-109, http://dx.doi.org/10.1016/j.solmat.2013. 04.008.

[6] D. Rudmann, G. Bilger, M. Kaelin, F.J. Haug, H. Zogg, A.N. Tiwari, Effects of NaF coevaporation on structural properties of $\mathrm{Cu}(\mathrm{In}, \mathrm{Ga}) \mathrm{Se}_{2}$ thin films, Thin Solid Films 431-432 (2003) 37-40, http://dx.doi.org/10.1016/S0040-6090(03)00246-3.

[7] R.V. Forest, B.E. McCandless, X. He, A.A. Rockett, E. Eser, K.D. Dobson, R.W. Birkmire, Diffusion of sodium in single crystal CuInSe $e_{2}$, J. Appl. Phys. 121 (2017) 245102, http://dx.doi.org/10.1063/1.4986635.

[8] Z.-K. Yuan, S. Chen, Y. Xie, J.-S. Park, H. Xiang, X.-G. Gong, S.-H. Wei, Na-diffusion enhanced p-type conductivity in $\mathrm{Cu}(\mathrm{In}, \mathrm{Ga}) \mathrm{Se}_{2}$ : a new mechanism for efficient doping in semiconductors, Adv. Energy Mater. 6 (2016) 1601191, http://dx.doi. org/10.1002/aenm.201601191.

[9] F. Werner, D. Colombara, M. Melchiorre, N. Valle, B.El Adib, C. Spindler, S. Siebentritt, Doping mechanism in pure CuInSe ${ }_{2}$, J. Appl. Phys. 119 (2016) 173103, http://dx.doi.org/10.1063/1.4947585.

[10] A. Chirilă, P. Reinhard, F. Pianezzi, P. Bloesch, A.R. Uhl, C. Fella, L. Kranz, D. Keller, C. Gretener, H. Hagendorfer, D. Jaeger, R. Erni, S. Nishiwaki, S. Buecheler, A.N. Tiwari, Potassium-induced surface modification of $\mathrm{Cu}(\mathrm{In}, \mathrm{Ga}) \mathrm{Se}_{2}$ thin films for high-efficiency solar cells, Nat. Mater. 12 (2013) 1107-1111, http:// dx.doi.org/10.1038/nmat3789.

[11] P. Jackson, D. Hariskos, R. Wuerz, W. Wischmann, M. Powalla, Compositional investigation of potassium doped $\mathrm{Cu}(\mathrm{In}, \mathrm{Ga}) \mathrm{Se}_{2}$ solar cells with efficiencies up to 20.8\%, Phys. Status Solidi (RRL) 8 (2014) 219-222, http://dx.doi.org/10.1002/ pssr.201409040.

[12] P. Jackson, R. Wuerz, D. Hariskos, E. Lotter, W. Witte, M. Powalla, Effects of heavy alkali elements in $\mathrm{Cu}(\mathrm{In}, \mathrm{Ga}) \mathrm{Se}_{2}$ solar cells with efficiencies up to $22.6 \%$, Phys. Status Solidi (RRL) 10 (2016) 583-586, http://dx.doi.org/10.1002/pssr. 201600199.

[13] Solar frontier achieves world record thin-film solar cell efficiency of $22.9 \%$, http:// www.solar-frontier.com/eng/news/2017/1220_press.html, (2017) , Accessed date: 11 January 2018.

[14] D. Braunger, D. Hariskos, G. Bilger, U. Rau, H.W. Schock, Influence of sodium on the growth of polycrystalline $\mathrm{Cu}(\mathrm{In}, \mathrm{Ga}) \mathrm{Se}_{2}$ thin films, Thin Solid Films 361-362 (2000) 161-166, http://dx.doi.org/10.1016/S0040-6090(99)00777-4. 
[15] O. Cojocaru-Mirédin, P. Choi, R. Wuerz, D. Raabe, Atomic-scale distribution of impurities in CuInSe $e_{2}$-based thin-film solar cells, Ultramicroscopy 111 (2011) 552-556, http://dx.doi.org/10.1016/j.ultramic.2010.12.034.

[16] L. Kronik, D. Cahen, H.W. Schock, Effects of sodium on polycrystalline $\mathrm{Cu}(\mathrm{In}, \mathrm{Ga}) \mathrm{Se}_{2}$ and its solar cell performance, Adv. Mater. 10 (1998) 31-36, http://dx.doi.org/10. 1002/(sici)1521-4095(199801)10:1 < 31::aid-adma31 > 3.0.co;2-3.

[17] M. Malitckaya, H.-P. Komsa, V. Havu, M.J. Puska, Effect of alkali metal atom doping on the CuInSe ${ }_{2}$-based solar cell absorber, J. Phys. Chem. C 121 (2017) 15516-15528, http://dx.doi.org/10.1021/acs.jpcc.7b03083.

[18] D. Colombara, U. Berner, A. Ciccioli, J.C. Malaquias, T. Bertram, A. Crossay, M. Schöneich, H.J. Meadows, D. Regesch, S. Delsante, G. Gigli, N. Valle, J. Guillot, B.E. Adib, P. Grysan, P.J. Dale, Deliberate and accidental gas-phase alkali doping of chalcogenide semiconductors: $\mathrm{Cu}(\mathrm{In}, \mathrm{Ga}) \mathrm{Se}_{2}$, Sci. Rep. 7 (2017) 43266, http://dx. doi.org/10.1038/srep43266.

[19] E. Zurek, P.P. Edwards, R. Hoffmann, A molecular perspective on lithium-ammonia solutions, Angew. Chem. Int. Ed. 48 (2009) 8198-8232, http://dx.doi.org/10. 1002/anie.200900373.

[20] W. Klemm, H. Sodomann, P. Langmesser, Beiträge Zur Kenntnis der Alkalimetallchalkogenide, Z. Anorg. Allg. Chem. 241 (1939) 281-304, http://dx. doi.org/10.1002/zaac.19392410216.

[21] E. Zintl, A. Harder, B. Dauth, Gitterstruktur der Oxyde, Sulfide, Selenide und Telluride des Lithiums, Natriums und Kaliums, Z. Elektrochem. Angew. Phys. Chem. 40 (1934) 588-593, http://dx.doi.org/10.1002/bbpc.19340400811.

[22] G.W. Watt, W.B. Leslie, T.E. Moore, Liquid ammonia research-1941, Chem. Rev. 31 (1942) 525-536, http://dx.doi.org/10.1021/cr60100a001.

[23] A.J. Birch, The Birch reduction in organic synthesis, Pure Appl. Chem. 68 (1996) 553-556, http://dx.doi.org/10.1351/pac199668030553.

[24] C.A. Kraus, Solutions of metals in non-metallic solvents; I. General properties, J. Am. Chem. Soc. 29 (1907) 1557-1571, http://dx.doi.org/10.1021/ja01965a003.

[25] J.L. Dye, Electrons as anions, Science 301 (2003) 607-608, http://dx.doi.org/10 1126 /science.1088103.

[26] A. Chandra, D. Marx, Creating interfaces by stretching the solvent is key to metallic ammonia solutions, Angew. Chem. Int. Ed. 46 (2007) 3676-3679, http://dx.doi. org/10.1002/anie.200604431.

[27] V.V. Chaban, O.V. Prezhdo, Electron solvation in liquid ammonia: lithium, sodium, magnesium, and calcium as electron sources, J. Phys. Chem. B 120 (2016) 2500-2506, http://dx.doi.org/10.1021/acs.jpcb.6b00412.

[28] D. Colombara, P.J. Dale, G.P. Kissling, L.M. Peter, S. Tombolato, Photoelectrochemical screening of solar cell absorber layers: electron transfer kinetics and surface stabilization, J. Phys. Chem. C 120 (2016) 15956-15965, http:// dx.doi.org/10.1021/acs.jpcc.5b12531.

[29] A.-M. Gonçalves, L. Santinacci, A. Eb, C. David, C. Mathieu, M. Herlem, A. Etcheberry, New porosification of $\mathrm{n}-\mathrm{InP}$ and $\mathrm{n}$-GaAs in acidic liquid ammonia at $223 \mathrm{~K}$ : unusual morphologies associated to distinguished electrochemical behaviours, Phys. Status Solidi A 204 (2007) 1286-1291, http://dx.doi.org/10.1002/ pssa.200674311.

[30] N.L. Bill, O. Trukhina, J.L. Sessler, T. Torres, Supramolecular electron transferbased switching involving pyrrolic macrocycles. A new approach to sensor development? Chem. Commun. 51 (2015) 7781-7794, http://dx.doi.org/10.1039/ C4CC10193F.

[31] P. Ji, J.H. Atherton, M.I. Page, The kinetics and mechanisms of organic reactions in liquid ammonia, Faraday Discuss. 145 (2010) 15-25, http://dx.doi.org/10.1039/ B912261N.

[32] A. Greenfield, U. Schindewolf, Kinetics of the Birch reduction, Ber. Bunsenges. Phys. Chem. 102 (1998) 1808-1814, http://dx doi.org/10.1002/bbpc.19981021211.

[33] C. Schöttle, P. Bockstaller, D. Gerthsen, C. Feldmann, Tungsten nanoparticles from liquid-ammonia-based synthesis, Chem. Commun. 50 (2014) 4547-4550, http://dx. doi.org/10.1039/C3CC49854A.

[34] H. Feng, Y. Liu, J. Li, Highly reduced graphene oxide supported Pt nanocomposites as highly efficient catalysts for methanol oxidation, Chem. Commun. 51 (2015)
2418-2420, http://dx.doi.org/10.1039/C4CC09146A.

[35] K.W. Sharp, W.H. Koehler, Synthesis and characterization of sodium polyselenides in liquid ammonia solution, Inorg. Chem. 16 (1977) 2258-2265, http://dx.doi.org/ 10.1021/ic50175a021.

[36] A.-M. Gonçalves, N. Simon, S. Channoug, D. Aureau, C. Mathieu, A. Etcheberry, Stability of InP oxide versus solvated electrons in liquid ammonia, Comptes Rendus Chimie 16 (2013) 34-38, http://dx.doi.org/10.1016/j.crci.2012.01.010.

[37] D. Guyomard, C. Mathieu, M. Herlem, In situ modification of the energetic structure of the $\mathrm{n}-\mathrm{GaP} / \mathrm{NH}_{3}$ junction in the presence of solvated electrons, J. Electroanal. Chem. Interfacial Electrochem. 246 (1988) 29-42, http://dx.doi.org/10.1016/ 0022-0728(88)85048-4.

[38] J.L. Dye, Solvated-electron reaction rates in amines, Acc. Chem. Res. 1 (1968) 306-312, http://dx.doi.org/10.1021/ar50010a003.

[39] T. Teherani, K. Itaya, A.J. Bard, An electrochemical study of solvated electrons in liquid ammonia, Nouv. J. Chim. 2 (1978) 481-487.

[40] W.J. Albery, S. Bruckenstein, Uniformly accessible electrodes, J. Electroanal. Chem. Interfacial Electrochem. 144 (1983) 105-112, http://dx.doi.org/10.1016/S0022 0728(83)80148-X.

[41] A.J. Bard, L.R. Faulkner, Electrochemical Methods, Fundamentals and Applications, Wiley, 2001.

[42] Y. Harima, S. Aoyagui, The diffusion coefficient of solvated electrons in liquid ammonia, J. Electroanal. Chem. Interfacial Electrochem. 109 (1980) 167-177, http://dx.doi.org/10.1016/S0022-0728(80)80115-X.

[43] J.L. Dye, R.F. Sankuer, G.E. Smith, Ion transport in sodium-ammonia solutions, J. Am. Chem. Soc. 82 (1960) 4797-4803, http://dx.doi.org/10.1021/ja01503a011.

[44] I. Schewe-Miller, P. Böttcher, Synthesis and crystal structures of $\mathrm{K}_{5} \mathrm{Se}_{3}, \mathrm{Cs}_{5} \mathrm{Te}_{3}$ and $\mathrm{Cs}_{2}$ Te, Z. Krist. 196 (1991) 137-151, http://dx.doi.org/10.1524/zkri.1991.196.1-4 137.

[45] P. Böttcher, J. Getzschmann, R. Keller, Zur Kenntnis der Dialkalimetalldichalkogenide $\beta-\mathrm{Na}_{2} \mathrm{~S}_{2}, \mathrm{~K}_{2} \mathrm{~S}_{2}, \alpha-\mathrm{Rb}_{2} \mathrm{~S}_{2}, \beta-\mathrm{Rb}_{2} \mathrm{~S}_{2}, \mathrm{~K}_{2} \mathrm{Se}_{2}, \mathrm{Rb}_{2} \mathrm{Se}_{2}, \alpha$ $\mathrm{K}_{2} \mathrm{Te}_{2}, \beta-\mathrm{K}_{2} \mathrm{Te}_{2}$ und $\mathrm{Rb}_{2} \mathrm{Te}_{2}$, Z. Anorg. Allg. Chem. 619 (1993) 476-488, http://dx. doi.org/10.1002/zaac.19936190309.

[46] J. Getzschmann, E. Rönsch, P. Böttcher, Crystal structure of dinatriumtetraselenide $\mathrm{Na}_{2} \mathrm{Se}_{4}$, Zeitschrift für Kristallographie - New Crystal Structures 212 (1997) 87, http://dx.doi.org/10.1524/ncrs.1997.212.jg.87.

[47] V. Müller, G. Frenzen, K. Dehnicke, Synthese, FIR-Spektren und Kristallstrukturen der Pentaselenide $\mathrm{K}_{2} \mathrm{Se}_{5}$ und $[\mathrm{Na}(15-\mathrm{Krone}-5)]_{2} \mathrm{Se}_{5}$, Zeitschrift für Naturforschung B 47 (1992) 205-210.

[48] R. Kaplow, T.A. Rowe, B.L. Averbach, Atomic arrangement in vitreous selenium, Phys. Rev. 168 (1968) 1068-1079, http://dx.doi.org/10.1103/PhysRev.168.1068.

[49] N.N. Greenwood, A. Earnshaw, Chemistry of the Elements, Pergamon Press, 1984

[50] Å. Olin, B. Nolang, E.G. Osadchii, L.-O. Ohman, E. Rosen, Chemical Thermodynamics of Selenium, Elsevier Science, 2005, http://ropugipu.over-blog. co.uk/article-chemical-thermodynamics-of-selenium-download-pdf-109878926. html.

[51] B. Gates, B. Mayers, B. Cattle, Y. Xia, Synthesis and characterization of uniform nanowires of trigonal selenium, Adv. Funct. Mater. 12 (2002) 219-227, http://dx doi.org/10.1002/1616-3028(200203)12:3<219::AID-ADFM219>3.0.CO;2-U.

[52] A. Goldbach, J. Johnson, D. Meisel, L.A. Curtiss, M.-L. Saboungi, On the constituents of aqueous polyselenide electrolytes: a combined theoretical and Raman spectroscopic study, J. Am. Chem. Soc. 121 (1999) 4461-4467, http://dx.doi.org/ 10.1021/ja9836186.

[53] R. Guidelli, R.G. Compton, J.M. Feliu, E. Gileadi, J. Lipkowski, W. Schmickler, S. Trasatti, Definition of the transfer coefficient in electrochemistry (IUPAC Recommendations 2014), Pure Appl. Chem. 86 (2014) 259-262, http://dx.doi.org/ 10.1515/pac-2014-5025.

[54] N.M. Alpatova, L.I. Krishtalik, Y.V. Pleskov, Electrochemistry of solvated electrons, Organolithium Compounds/Solvated Electrons, Springer Berlin Heidelberg, 1987, pp. 149-219, , http://dx.doi.org/10.1007/3-540-16931-8_9. 